Research article

\title{
Plant growth promotion and Penicillium citrinum
}

\author{
Sumera Afzal Khan ${ }^{1,7}$, Muhammad Hamayun ${ }^{2}$, Hyeokjun Yoon ${ }^{1}$, Ho- \\ Youn Kim ${ }^{6}$, Seok-Jong Suh ${ }^{1}$, Seon-Kap Hwang ${ }^{1}$, Jong-Myeong Kim ${ }^{1}$, In- \\ Jung Lee ${ }^{2}$, Yeon-Sik Choo ${ }^{3}$, Ung-Han Yoon ${ }^{3}$, Won-Sik Kong5, Byung- \\ Moo Lee ${ }^{4}$ and Jong-Guk Kim*1
}

\begin{abstract}
Address: ${ }^{1}$ Department of Life Science and Biotechnology, Kyungpook National University, South Korea, ${ }^{2}$ Department of Agronomy, Kyungpook National University, South Korea, ${ }^{3}$ Department of Biology, Kyungpook National University, South Korea, ${ }^{4}$ Department of Agricultural Bioresource, National Academy of Agricultural Science, RDA, South Korea, ${ }^{5}$ Department of Herbal Crop Research, National Institute of Horiticultural \& Herbal Science, RDA, South Korea, ${ }^{6}$ Department of Horticulture, University of California-Davis, USA and ${ }^{7}$ Center of Biotechnology, University of Peshawar, Pakistan

Email: Sumera Afzal Khan - shumakhan@gmail.com; Muhammad Hamayun - hamayun73@gmail.com;

Hyeokjun Yoon-012yhj@hanmail.net; Ho-Youn Kim - jsakim@ucdavis.edu; Seok-Jong Suh - good_stone@hanmail.net; Seon-

Kap Hwang - hwangs@cahnrs.wsu.edu; Jong-Myeong Kim - jongmykim@naver.com; In-Jung Lee - ijlee@knu.ac.kr; Yeon-

Sik Choo - yschoo@knu.ac.kr; Ung-Han Yoon - uhyoon@rda.go.kr; Won-Sik Kong - wskong@rda.go.kr; Byung-

Moo Lee-4861aa@hanmail.net; Jong-Guk Kim* - kimjg@knu.ac.kr

* Corresponding author
\end{abstract}

Published: 22 December 2008

BMC Microbiology 2008, 8:23| doi:|0.||86/|47|-2|80-8-23|
Received: 29 August 2008

Accepted: 22 December 2008

This article is available from: http://www.biomedcentral.com/|47|-2/80/8/23।

(C) 2008 Khan et al; licensee BioMed Central Ltd.

This is an Open Access article distributed under the terms of the Creative Commons Attribution License (http://creativecommons.org/licenses/by/2.0), which permits unrestricted use, distribution, and reproduction in any medium, provided the original work is properly cited.

\begin{abstract}
Background: Endophytic fungi are known plant symbionts. They produce a variety of beneficial metabolites for plant growth and survival, as well as defend their hosts from attack of certain pathogens. Coastal dunes are nutrient deficient and offer harsh, saline environment for the existing flora and fauna. Endophytic fungi may play an important role in plant survival by enhancing nutrient uptake and producing growth-promoting metabolites such as gibberellins and auxins. We screened roots of Ixeris repenes (L.) A. Gray, a common dune plant, for the isolation of gibberellin secreting endophytic fungi.
\end{abstract}

Results: We isolated 15 endophytic fungi from the roots of Ixeris repenes and screened them for growth promoting secondary metabolites. The fungal isolate IR-3-3 gave maximum plant growth when applied to waito-c rice and Atriplex gemelinii seedlings. Analysis of the culture filtrate of IR-3-3 showed the presence of physiologically active gibberellins, $\mathrm{GA}_{1}, \mathrm{GA}_{3}, \mathrm{GA}_{4}$ and $\mathrm{GA}_{7}(\mathrm{l} .95 \mathrm{ng} / \mathrm{ml}, 3.83 \mathrm{ng} / \mathrm{ml}, 6.03 \mathrm{ng} / \mathrm{ml}$ and $2.35 \mathrm{ng} / \mathrm{ml}$, respectively) along with other physiologically inactive $\mathrm{GA}_{5}, \mathrm{GA}_{9}, \mathrm{GA}_{12}, \mathrm{GA}_{15}, \mathrm{GA}_{19}, \mathrm{GA}_{20}$ and, $\mathrm{GA}_{24}$. The plant growth promotion and gibberellin producing capacity of IR-3-3 was much higher than the wild type Gibberella fujikuroi, which was taken as control during present study. $\mathrm{GA}_{5}$, a precursor of bioactive $\mathrm{GA}_{3}$ was reported for the first time in fungi. The fungal isolate IR-3-3 was identified as a new strain of Penicillium citrinum (named as P. citrinum KACC43900) through phylogenetic analysis of I8S rDNA sequence.

Conclusion: Isolation of new strain of Penicillium citrinum from the sand dune flora is interesting as information on the presence of Pencillium species in coastal sand dunes is limited. The plant growth promoting ability of this fungal strain may help in conservation and revegetation of the rapidly eroding sand dune flora. Penicillium citrinum is already known for producing mycotoxin citrinin and cellulose digesting enzymes like cellulase and endoglucanase, as well as xylulase. Gibberellins producing ability of this fungus and the discovery about the presence of $\mathrm{GA}_{5}$ will open new aspects of research and investigations. 


\section{Background}

Gibberellins (GAs) is a family of diterpenoid plant hormones, first detected in 1930s from culture filtrates of Gibberella fujikuroi, a known pathogen of rice plants $[1,2]$. In 1956, GA was isolated and identified as plant hormone from the extracts of higher plants [3]. GA appear to be involved in every aspect of plant growth and development, but their most typical (and spectacular) property is the enhancement of stem growth [4]. GA may modify the sex expression of flowers, induce the parthenocarpic development of fruit and delay senescence. They obviate the need for exposure to red light in the germination of seeds and spores, and the need for vernalisation in the growth of bulbs and tubers. They are associated with the breaking of winter dormancy and stimulate the formation of hydrolytic enzymes in germinating cereal grain [5]. Currently 136 GAs have been identified, while 12 fungi, pathogenic and non-pathogenic, associated with plants and/or soil has been reported as GA producers $[6,7]$.

Endophytic fungi have been found to colonize the roots of plants [8] and have usually been defined as those fungi growing asymptomatically within the tissues of their host plants, excluding pathogenic fungi and mycorrhizae $[9,10]$. This relationship is subjected to change and replacement by other endophytes depending on environmental conditions [11] and host requirement. Fungal endophytes of roots can therefore be defined as those fungi located within apparently healthy, functional root tissues at the moment of sample collection [8]. Unlike mycorrhizal fungi, endophytes reside entirely within host tissues and may emerge during host senescence [12]. Endophytes have been shown to confer fitness benefits to host plants including tolerance to herbivory, heat, salt, disease, and drought, and increased below- and aboveground biomass [8,13-17]. Endophytic colonization may also improve the ecological adaptability of the host by enhancing tolerance to biotic and abiotic stresses $[11,18]$. Penicillium citrinum has been reported as common endophytic fungus of cereal plants like wheat and soybean. It had been isolated from different environmental conditions, ranging from permafrost sediments to agricultural fields and forest soils. It is most vigorously studied laboratory taxon that gained importance after discovery of well-known mycotoxin citrinin. Currently it is being explored for different secondary metabolites it can produce and their associated benefits [19-23].

Sand dunes in coastal regions of South Korea are being destroyed due to anthropogenic disturbances such as military action as well as beach construction and recreational activities. The intensity of artificial activities had affected the speed and efficiency of their conservation and revegetation $[24,25]$. We investigated root endophytic fungi of sand-dune flora for GAs production as such work had not been carried out in the past. This paper report screening of
Ixeris repens, a common plant of sandy beaches across East Asian countries $[25,26]$ for plant growth promoting metabolites by root endophytic fungi.

\section{Results}

Screening for plant growth promoting activity of fungal metabolites on waito-c rice

Fifteen endophytic fungi were isolated from roots of Ixeris repens, collected from sand dune at Pohang beach, Korean peninsula. The fungal culture filtrates were applied on waito-c rice seedlings and the length of seedlings was checked after one week of fungal culture filtrate application. Out of 15 isolated fungi, 2 fungal isolates considerably promoted shoot lengths of rice seedlings. The fungal isolate IR-3-3 gave maximum plant and shoot length of $22.35 \mathrm{~cm}$ and $12.60 \mathrm{~cm}$ respectively, while culture filtrate of IR-10-3 gave plant height of $17.75 \mathrm{~cm}$ and shoot length of $7.1 \mathrm{~cm}$. The plant and shoot growth promotion by $G$. fujikuroi was much lower than IR-3-3, which was thus selected for further investigation (Figure 1).

\section{Bioassy of IR-3-3 for plant growth promoting activity on Atriplex gemelinii}

Since the growth rate of sand dune plants are much slower, shoot lengths of Atriplex gemelinii seedlings treated with IR-3-3 culture filtrate were measured after 15 days of culture filtrate application. The growth promoting capacity of IR-3-3 was compared with the results obtained from the application of culture filtrate of wild type G. fujikuroi and Czapek broth, separately. Since Czapek medium contain nutrients, its control was used to observe possibility of nutrients effect on shoot elongation. Shoot length of IR-3-3 culture filtrate treated seedlings was $3.6 \mathrm{~cm}$, which was higher than that of G. fujikuroi culture filtrate $(3.1 \mathrm{~cm})$ and Czapek broth $(2.0 \mathrm{~cm})$ treated seedlings (Figure 2).

\section{Analyses of culture filtrate of IR-3-3 for the presence of gibberellins}

Gibberellins analysis showed the presence of $\mathrm{GA}_{1}(1.95$ $\mathrm{ng} / \mathrm{ml}), \mathrm{GA}_{3}(3.83 \mathrm{ng} / \mathrm{ml}), \mathrm{GA}_{4}(6.03 \mathrm{ng} / \mathrm{ml}), \mathrm{GA}_{5}(0.365$ $\mathrm{ng} / \mathrm{ml}), \mathrm{GA}_{7}(2.35 \mathrm{ng} / \mathrm{ml}), \mathrm{GA}_{9}(0.65 \mathrm{ng} / \mathrm{ml}), \mathrm{GA}_{12}(0.11$ $\left.\mathrm{ng} / \mathrm{ml}), \mathrm{GA}_{15} 0.72 \mathrm{ng} / \mathrm{ml}\right), \mathrm{GA}_{19}(0.67 \mathrm{ng} / \mathrm{ml}), \mathrm{GA}_{20}(0.30$ $\mathrm{ng} / \mathrm{ml})$ and $\mathrm{GA}_{24}(1.40 \mathrm{ng} / \mathrm{ml})$ in culture filtrate of IR-3-3. Among them, $\mathrm{GA}_{1}, \mathrm{GA}_{3}, \mathrm{GA}_{4}$ and $\mathrm{GA}_{7}$ are physiologically active GAs (See Additional files 1, 2, 3, 4 for GC-MS SIM spectra of these GA). Fungal isolate IR-3-3 showed higher GAs productivity than wild type G. fujikuroi (see Figure 3). Important finding was the detection of $\mathrm{GA}_{5}$ in the culture filtrates of fungal isolate IR-3-3 and wild type G. fujikuroi (See Additional files 5 and 6 for GC-MS SIM spectra of this GA).

\section{Phylogenetic analysis}

The phylogenetic analysis of fungal isolate IR-3-3 was carried out by distance tree construction. We aligned ITS1 sequences of available $P$. citrinum through BLAST 


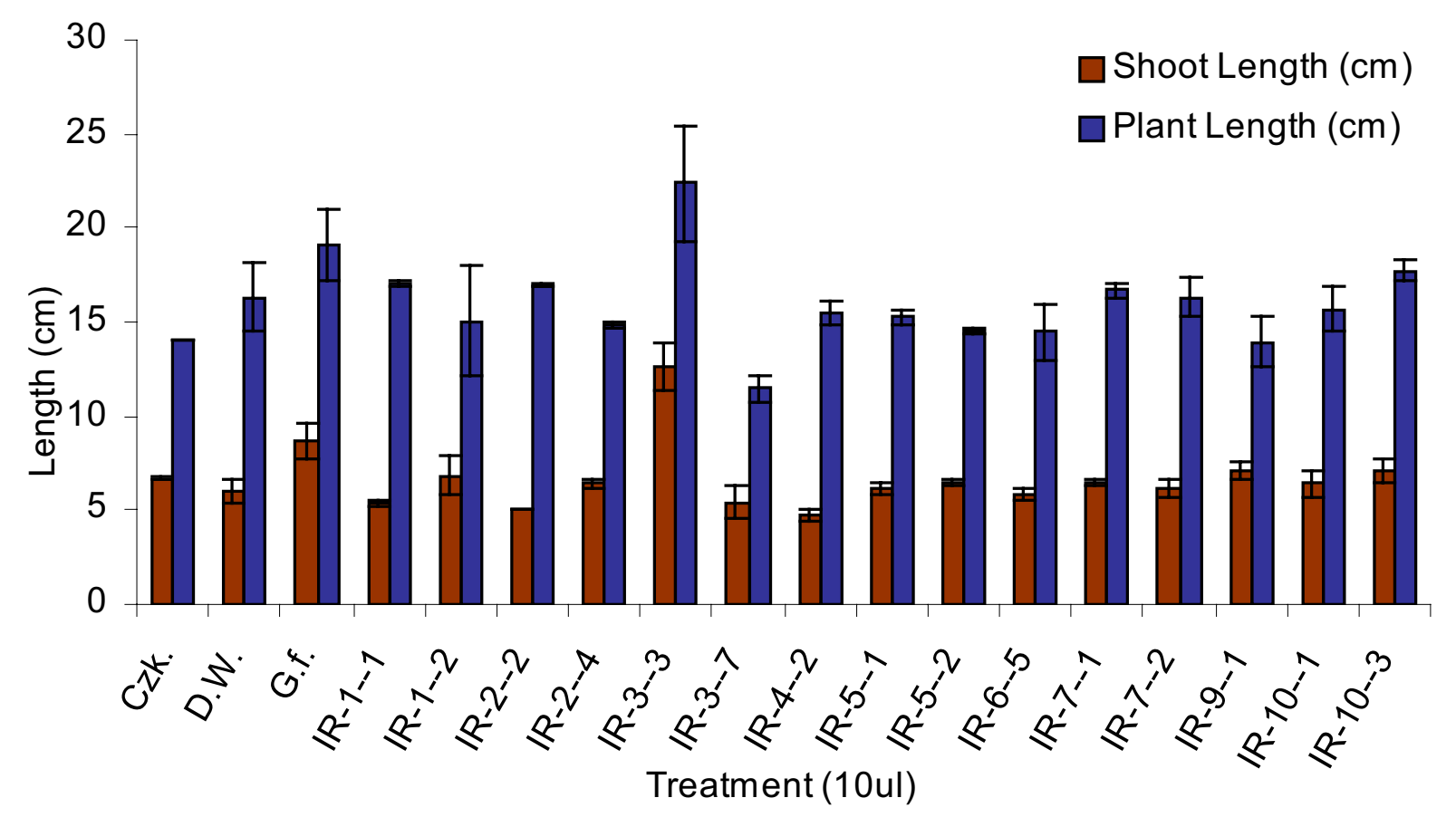

Czk: Czapek media; D.W.: Distilled water; G.f.: Gibberella fujikuroi

Figure I

Effect of fungal culture filtrates on length of waito-c rice seedlings after 7 days of incubation. The experiment was conducted in 3 replicates; standard deviation from means was calculated using MS-EXCEL. Whole plant lengths as well as shoot lengths were increased after 7 days of treatment with culture filtrate. Culture filtrates of IR-3-3 caused shoot elongation more than that by $G$ fujikuroi (Control III), but whole plant length was about same for both indicating little or no effect of filtrate on root elongation.

sequence using ClustalW and a neighbour joining tree was constructed from 22 (21 references and 1 clone) aligned sequences. A. fumigatus was used as an out group for tree rooting. The fungal isolate IR-3-3 gave 95\% bootstrap support for a monoclade of $P$. citrinum strains (1000 bootstrap replications), thus suggesting IR-3-3 as a new strain of $P$. citrinum (Figure 4).

On the basis of sequence homology and phylogenetic analysis, isolate IR-3-3 was thus identified as a new strain of $P$. citrinum. The ITS1 sequence of this strain has been submitted to GenBank database [GenBank: EU821333]. The fungal isolate was deposited to the Korean Agricultural Culture Collection (KACC) and was allotted no. KACC43900. The IR-3-3 was thus named as P. citrinum KACC43900.

\section{Discussion}

Endophytic fungi form mutualistic interactions with their host, the relationship therefore being beneficial for both partners [8]. Mutualism frequently leads to enhanced growth of the host. In current study, the presence of plant growth promoting metabolites in culture filtrates of our fungal strains were determined through a primary screening experiment on waito-c rice seedlings. Use of rice seedlings is beneficial as they easily grow under controlled and sterilized conditions, hydroponically, using autoclaved water-agar media. Since this media is devoid of any nutrient, the sole effect of culture filtrate can easily be estimated. Waito-c rice is a known dwarf rice cultivar with reduced GA biosynthesis. Treatment of its seeds with uniconazol, a GA biosynthesis retardant, further suppresses the endogenous GAs production by blocking its biosynthesis pathway in the plant. Shoot elongation of these seedlings can be easily attributed to the activity of plant growth promoting secondary metabolites from fungal culture filtrates $[27,28]$. The microbial extracts had been and will continue to be a productive source of biologically active compounds [8]. Screening of microbial secondary metabolites is an established method for the identification of novel and biologically active molecules [29-32].

The plant growth promoting capacity of fungal secondary metabolites was confirmed by conducting a bioassay experiment on seedlings of Atriplex gemelinii, a commonly occurring plant of sandy shores in China, Japan and Korea 


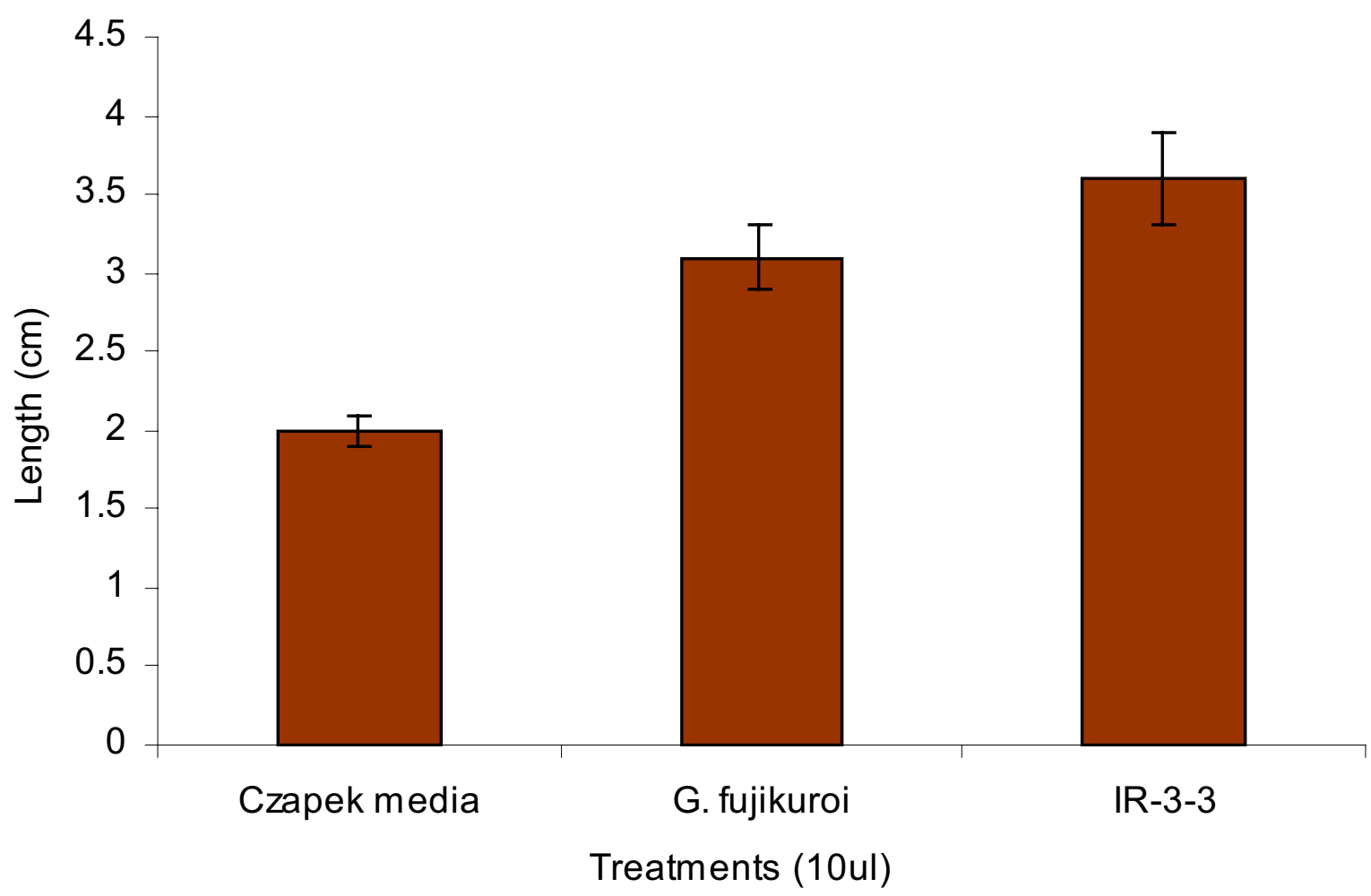

\section{Figure 2}

Effect of IR-3-3 culture filtrate on Atriplex gemelinii seedlings after I 5 days of application. The experiment was performed in 3 replicates; standard deviation from means was calculated using MS-EXCEL. Shoot lengths of seedlings were increased after I5 days of culture filtrate treatment. IR-3-3 culture filtrate treated seedlings showed increased shoot lengths than those by wild type $G$ fujikuroi indicating possibility of GAs production as secondary metabolite by the strain.

[26]. Seeds of this plant did not exhibit dormancy, and germinate by soaking in water in a week time. Being duneplant, it showed adaptation to nutrient deficiency, growing in hydroponic media ( $0.8 \%$ water-agar) without any supply of nutrient solution. Although germination is rapid in these plants, but they possess slow growth rate ( $0.5 \mathrm{~m}$ annually), therefore the seedling length was much lower than those of rice. However, considerable increase in its shoot lengths was observed, when treated with IR-33 as compared to control. Current findings confirmed the previous reports of shoot length promotion by fungal culture filtrate application $[27,28]$.

GA analysis of the culture filtrates of IR-3-3 and G. fujikuroi showed that bioactive GA production capacity of IR-3-3 was much higher than wild type G. fujikuroi, which narrates the significance of this newly isolated fungal strain. The discovery of $\mathrm{GA}_{5}$ in the culture filtrates of both IR-3-3 and G. fujikuroi will lead to the modification of fungal GA biosynthesis pathway by providing the missing links for GA biosynthesis in fungi. Gibberellins were analyzed with gas chromatograph-mass spectrometer (GCMS), which is a useful tool because of its ability to analyze highly complex mixtures and to detect compounds of different classes simultaneously. GC-MS techniques have been used in clinical medicine and were only recently introduced in plant research [30,33,34]. Recently, advances of mass spectrometry in food-related research [35] and aroma analysis [36] have been reported. Phytohormones quantification by GC-MS-SIM is well established and most reliable technique in ongoing investigations worldwide [27,28,37-39]. The major advantage of GC-MS is its unbiased character. In comparison with non-MS detection based chromatographic techniques (HPLC-DAD, GC-FID), where only compounds targeted by a special analytical protocol are found, GC-MS analysis can result in interesting and unexpected new knowledge about a particular extract [40]. Quantitative analysis is done by acquiring compound-specific molecular ions in selected ion monitoring (SIM) to increase the signal-to-noise ratio (SNR) of the MS experiment [41].

Approximately $70-80,000$ species of fungi exists [42]. Due to possible existence of different morpho/biotypes of fungi within single species, traditional morphological and biochemical methods are not considered reliable for iden- 


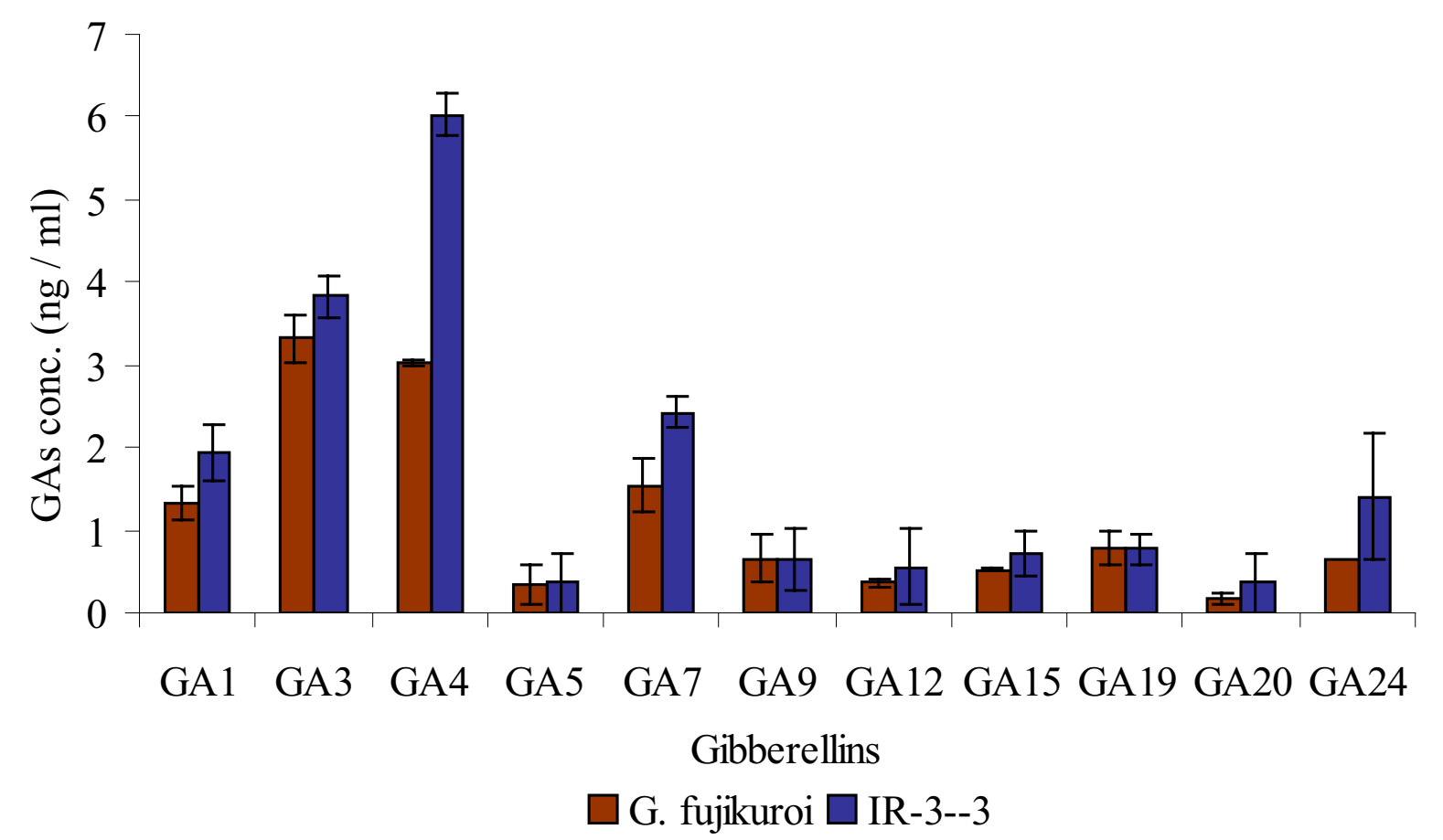

Figure 3

Gibberellins content of fungal isolate IR-3-3 and wild type G. fujikuroi. The experiment was performed in 3 replicates; standard deviation from means was calculated using MS-EXCEL. On GC-MS SIM analysis of culture filtrate extracts from IR-33 , all four bioactive GAs were detected higher than of $G$. fujikuroi. Non-bioactive $G A$ s including $G_{15}, G_{20}$ and $G A_{24}$ were in comparatively higher amounts, $\mathrm{GA}_{9}$ and $\mathrm{GA}_{19}$ were in about equal amounts, while $\mathrm{GA}_{12}$ was detected in amount lower than in case of control (G. fujikuroi).

tification [31]. On the other hand, DNA sequence analysis methods are objective, reproducible and rapid means of identification, and thus gaining importance and have commonly been used to identify non sporulating endophytes [43-45]. We used $5.8 \mathrm{~S}$ gene and flanking ITS1/4 regions for fungal identification. It is because highly conserved $5.8 \mathrm{~S}$ gene is suitable for higher taxanomic level analysis while highly variable ITS regions are useful for analysis at lower taxanomic levels $[42,46,47]$. Constructing phylogenetic tree is crucial in molecular identification, since BLAST search alone cannot overcome possibilities of statistical errors. Bootstrap consensus is applied to the constructed tree so as to read maximum sequence replications. Neighbour joining tree with bootstrapping gave us a clear picture for identifying fungal isolate IR-3-3. It is because more than 100 BLAST hits belonged to Penicillium genera, thus strongly recommending our isolate as a member of this group. Although many phylogenetic trees exist and are used for analysis, neighbour-joining method has been designated most reliable tree construction method especially when dealing with closely related strains under varying rates of evolution $[48,49]$.

\section{Conclusion}

From our study we can conclude that root endophytic fungi play very important roles for supporting their host plants. Under environmental stress condition like that of coastal zones, waterlogged and barren lands with few plants, the endophytic fungi with extraordinary metabolites might be isolated and identified, and their metabolites can be used for human and environmental benefits. Further studies with $P$. citrinum KACC43900 regarding characterization of GAs encoding genes and optimization of GAs production media are suggested.

\section{Methods}

\section{Plants, Fungal Strains, Culture Medium and Growth Conditions}

Screening and isolation of plant root fungi was carried out on Hagem minimal medium plates supplemented with $80 \mathrm{ppm}$ Streptomycin [50,51]. For storage, potato dextrose agar (PDA) plates and slants were used, while Czapek broth medium containing $1 \%$ glucose and peptone was used for Gibberellin production [52] by incubating strains at $30^{\circ} \mathrm{C}$ and $120 \mathrm{rpm}$ for 7 days. The wild type strain of Gibberella fujikuroi provided by the Korean Culture Center of Microorganisms (KCCM) was used as a control during the experiment.

\section{Isolation of endophytic fungi from roots of Ixeris repens}

The root samples were washed with tap water to remove sand particles and other debris, treated with Tween 80 


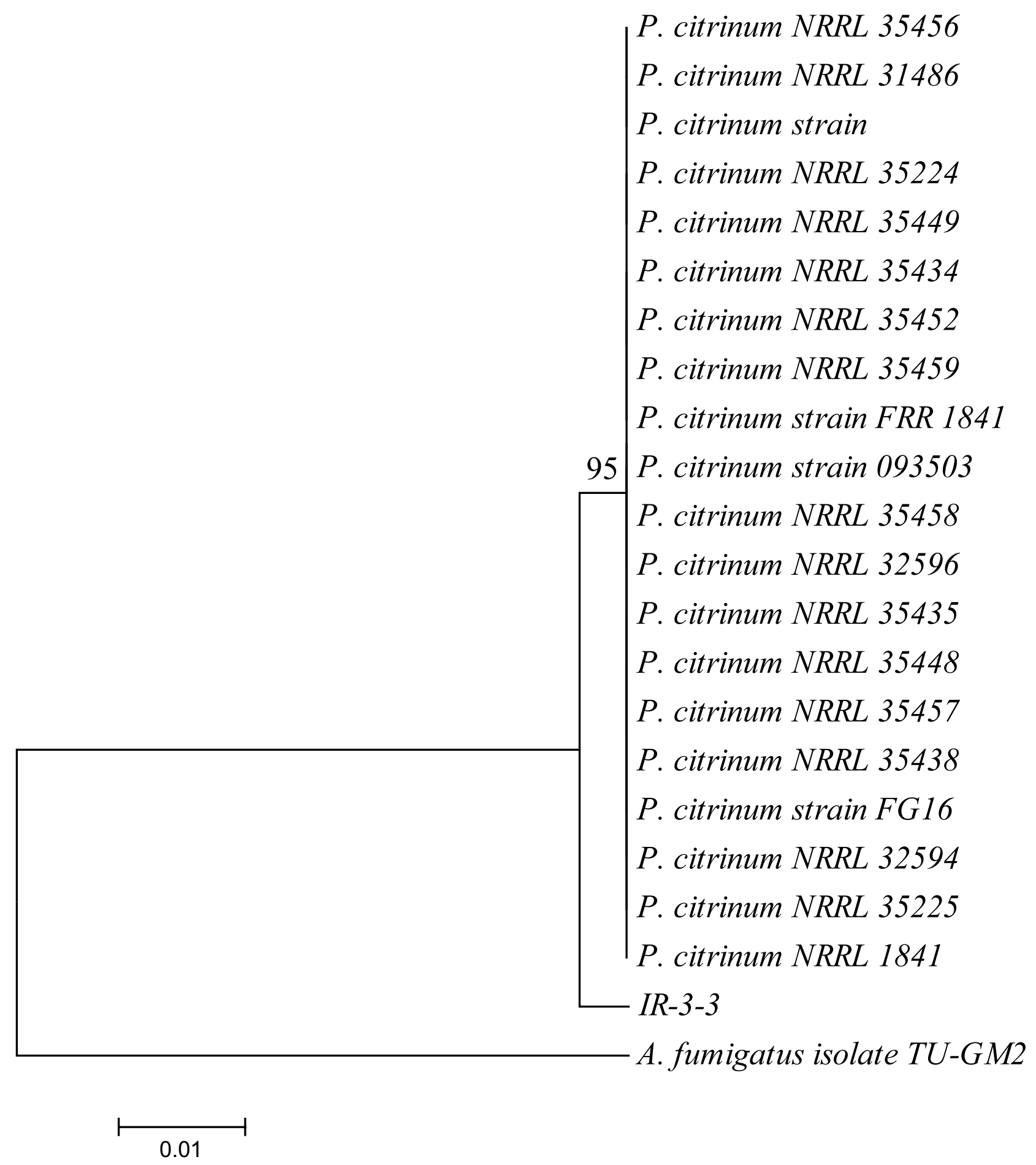

Figure 4

Phylogenetic analysis of isolate IR-3-3. A neighbor joining tree was constructed with 22 strains (2I strains of $P$. citrinum obtained through Blast, and one clone strain IR-3-3). A. fumigatus was used as outgroup for rooting the tree. Fungal isolate IR3-3 formed $95 \%$ bootstrap support for monoclade formed by all members of $P$. citrinum, after 1000 bootstrap replications, strongly supporting its identification as a new strain of $P$. citrinum. 
solution and surface sterilized using perchloric acid (1\%) solution. The surface sterilized roots were then cut into $0.5 \mathrm{~cm}$ pieces in laminar flow hood, cultured on Hagem media plates and, incubated at $25^{\circ} \mathrm{C}$ until emergence of fungi from inside of root pieces $[53,54]$. The isolated pure cultures of root fungi were stored on PDA plates and slants. Effectiveness of surface sterilization procedure was determined by imprinting sterilized root pieces on Hagem plates. Absence of any microbial growth on imprinted plates after 4-7 days of incubation were considered enough for effective surface sterilization of roots.

\section{Screening of fungal culture filtrate for plant growth promoting metabolites on rice}

The culture filtrate of fungal isolate was bioassayd on waito-c rice seedlings for the presence of plant growth promoting metabolites. For this purpose, the fungal isolate was grown in Czapek broth medium, on a shaking incubator for 7 days at $30^{\circ} \mathrm{C}$ and $120 \mathrm{rpm}$. Forty $\mathrm{ml}$ of culture fluid was harvested through centrifugation at $5000 \times \mathrm{g}$ at $4{ }^{\circ} \mathrm{C}$ for $15 \mathrm{~min}$. The harvested pellet and supernatant were immediately stored at $-70^{\circ} \mathrm{C}$ and later lyophilized. The lyophilized supernatant was mixed with $1 \mathrm{ml}$ autoclaved distilled water. Surface sterilized seeds [55] were incubated overnight with Uniconazol (Sumitomo Heavy Chemical Co. Ltd., Takarazuka, Japan), 20 ppm (in autoclaved distilled water), to further minimize activity of seed coat gibberellins. The treated seeds were washed thoroughly and soaked in autoclaved distilled water until radical emergence. The young seedlings were transplanted in glass tubes containing $0.8 \%$ water-agar medium and grown in a growth chamber. A $10 \mu \mathrm{l}$ of supernatant solution of fungal culture filtrate was applied on apical meristem of rice seedlings at two leaves stage. The shoot and plant length was observed after a week of culture filtrate application and compared with waito-c rice seedlings treated either with distilled water or culture filtrate of $G$. fujikuroi.

\section{Bioassay on Atriplex gemelinii}

The surface sterilized seeds [55] of Atriplex gemelinii were treated with uniconazol and then soaked in autoclaved distilled water for germination. The two leaves stage seedlings were treated with culture filtrate $(10 \mathrm{ul})$ of fungal strain IR-3-3. The shoot lengths were recorded after 15 days and compared with control treatments.

\section{Extraction and quantification of gibberellins}

Fungal gibberellins (GAs) were extracted from culture filtrates after 7 days of incubation in Czapek broth according to an established protocol [56]. Extracted GAs were subjected to reverse-phase C18-HPLC. The GAs were chromatographed on a $3.9 \times 300 \mathrm{~mm} \mu$ Bondapak, C18 column (Waters Corp., Milford, MA, USA) and eluted at 1.5 $\mathrm{ml} \mathrm{min}-1$ with the following gradient: 0 to $5 \mathrm{~min}$, isocratic
$28 \% \mathrm{MeOH}$ in $1 \%$ aqueous acetic acid; 5 to $35 \mathrm{~min}$, linear gradient from 28 to $86 \% \mathrm{MeOH} ; 35$ to $36 \mathrm{~min}, 86$ to $100 \% \mathrm{MeOH} ; 36$ to $40 \mathrm{~min}$, isocratic $100 \% \mathrm{MeOH}$. Up to forty fractions of $1.5 \mathrm{ml}$ each were collected. The fractions were then prepared for gas chromatograph/mass spectrometer (GC/MS) with selected ion monitoring (SIM) (6890N network GC system, and 5973 network mass selective detector; Agilent Technologies, Palo Alto, CA, USA). For each GA, $1 \mu \mathrm{l}$ of sample was injected in a $30 \mathrm{~m}$ $\times 0.25 \mathrm{~mm}$ (i.d.), $0.25 \mu \mathrm{m}$ film thickness DB-1 capillary column (J \& W Scientific Co., Folsom, CA, USA). The GC oven temperature was programmed for a 1 min hold at $60^{\circ} \mathrm{C}$, then to rise at $15^{\circ} \mathrm{C} \mathrm{min}^{-1}$ to $200^{\circ} \mathrm{C}$ followed by $5^{\circ} \mathrm{C}$ min $^{-1}$ to $285^{\circ} \mathrm{C}$. Helium carrier gas was maintained at a head pressure of $30 \mathrm{kPa}$. The GC was directly interfaced to a Mass Selective Detector with an interface and source temperature of $280^{\circ} \mathrm{C}$, an ionizing voltage of $70 \mathrm{eV}$ and a dwell time of $100 \mathrm{~ms}$. Full scan mode (the first trial), three major ions of the supplemented $\left[{ }^{2} \mathrm{H}_{2}\right]$ GAs internal standards (obtained from Prof. Lewis N. Mander, Australian National University, Canberra, Australia) and the fungal gibberellins were monitored simultaneously. The retention time was determined using hydrocarbon standards to calculate the KRI (Kovats Retention Index) value, while the GAs quantification was based on peak area ratios of non-deuterated (extracted) GAs to deuterated GAs.

\section{Genomic DNA extraction and gel electrophoresis}

An efficient method was developed for the isolation of genomic DNA from endophytic fungi, because usual CTAB extraction method and mycelial grinding was causing DNA shearing. Rich mycelial culture was obtained by growing fungus in Czapek culture broth (supplemented with $1 \%$ glucose and peptone) for 7 days on rotary shaking incubator $\left(120 \mathrm{rpm}\right.$ and $28^{\circ} \mathrm{C}$ ), and lyophilized for $24 \mathrm{hrs}$. A $0.5 \mathrm{~g}$ of lyophilized sample was broken carefully in $2 \mathrm{ml}$ eppendorf, with blunt end spatula or glass rod. Double volume of lysis buffer (20 mM Tris-HCL, pH8.0; $10 \mathrm{mM}$ EDTA; $1 \%$ SDS) containing $1 \%$ of 2 - mercaptoethanol was added. The mixture was vortexed briefly (30 sec) to obtain homogeneity and left to incubate for $2 \mathrm{hr}$ in water bath set at $55^{\circ} \mathrm{C} .250 \mu \mathrm{l} / \mathrm{ml}$ of pre-heated $4 \%$ СТАВ extraction buffer was added to lysed cells mixture and incubated further at $65^{\circ} \mathrm{C}$ for $1 \mathrm{hr}$. Chloroform extraction followed by iso-propanol precipitation yielded condensed strand of nucleic acid, which was cleaned from RNA using $10 \mathrm{ul}$ of RNase A for $2 \mathrm{hr}$ of incubation at $37^{\circ} \mathrm{C}$. The isolated DNA was suspended in $50 \mathrm{ul}$ of autoclaved deionized distilled water and tested for purity and quantity by agarose gel electrophoresis.

\section{$P C R$ and identification}

Fungal isolate was identified by sequencing internal transcribed region (ITS) of $18 \mathrm{~S}$ rDNA, using universal primers ITS-1 (5'-TCC GTA GGT GAA CCT GCG G-3') and ITS-4 
(5'-TCC TCC GCT TAT TGA TAT GC-3'). A $25 \mu \mathrm{l}$ of PCR mixture contained $2.5 \mu \mathrm{l}$ of dNTPs and Ex-Taq buffer, $2 \mu \mathrm{l}$ of each primer, $0.5 \mu \mathrm{l}$ of DNA sample, and $0.2 \mu \mathrm{l}$ of Ex-Taq polymerase. Rest volume was adjusted with $15.3 \mu \mathrm{l}$ of autoclaved deionized distilled water. The reaction cycle consisted of 2 min of initial denaturation at $95^{\circ} \mathrm{C}$, followed by 35 cycles of $30 \mathrm{sec}$ denaturation time $\left(95^{\circ} \mathrm{C}\right), 60$ sec of annealing $\left(55^{\circ} \mathrm{C}\right)$ and $30 \mathrm{sec}$ of extension $\left(72^{\circ} \mathrm{C}\right)$, and a final extension time of $5 \mathrm{~min}$ at $72^{\circ} \mathrm{C}$. The resultant product was gene cleaned using Nucleogen gene clean kit, ligated in T-vector using Takara Perfect T-cloning kit, and then inserted into DH $\alpha$ E. coli mutant cells (RBC) by overnight incubation $\left(37^{\circ} \mathrm{C}\right)$. Plasmids with inserts were extracted using SolGent Plasmid mini-prep kit, and sequenced.

\section{Phylogenetic analysis}

The BLAST search program http://www.ncbi.nlm.nih.gov/ BLAST/ was used to look for nucleotide sequence homology for 18S ITS (1/4) region for fungi. The obtained sequences were aligned by ClustalW using MEGA version 4.0 software [57], and the neighbor-joining tree was generated using same software. Bootstrap replication (1000 replications) was used for a statistical support for the nodes in the phylogenetic tree.

\section{Authors' contributions}

SAK and MH participated equally in overall experimentation and manuscript preparation. JGK, WSK and BML participated in design of the study. YSC and UHY participated in sampling area selection, plant collection and identification. SJS, SKH and JMK helped in root screening for fungal isolation. MH, HYK and IJL participated in gibberellins extraction and quantification. HY and JGK helped in gene isolation and identification. All authors read and approved the final manuscript.

\section{Additional material}

\section{Additional file 1}

GC-MS SIM spectra for $G A_{1}$ in culture filtrate of fungal isolate IR-33. Arrow indicates the peak of fungal $G A_{1}$ that coincides with that of internal standard $G A_{1}$.

Click here for file

[http://www.biomedcentral.com/content/supplementary/1471-

2180-8-231-S1.pdf]

\section{Additional file 2}

GC-MS SIM spectra for $\mathrm{GA}_{3}$ in culture filtrate of fungal isolate IR-33. Arrow indicates the peak of fungal GA3 that coincides with that of internal standard GA3.

Click here for file

[http://www.biomedcentral.com/content/supplementary/14712180-8-231-S2.pdf]

\section{Additional file 3}

GC-MS SIM spectra for $\mathrm{GA}_{4}$ in culture filtrate of fungal isolate IR-33. Arrow indicates the peak of fungal $\mathrm{GA}_{4}$ that coincides with that of internal standard $\mathrm{GA}_{4}$.

Click here for file

[http://www.biomedcentral.com/content/supplementary/1471-

2180-8-231-S3.pdf]

\section{Additional file 4}

GC-MS SIM spectra for $\mathrm{GA}_{7}$ in culture filtrate of fungal isolate IR-33. Arrow indicates the peak of fungal $G A_{7}$ that coincides with that of internal standard $G A_{7}$.

Click here for file

[http://www.biomedcentral.com/content/supplementary/1471-

2180-8-231-S4.pdf]

\section{Additional file 5}

GC-MS SIM spectra for $G_{5}$ in culture filtrate of fungal isolate IR-33. Arrow indicates the peak of fungal $G A_{5}$ that coincides with that of internal standard $G A_{5}$.

Click here for file

[http://www.biomedcentral.com/content/supplementary/1471-

2180-8-231-S5.pdf]

\section{Additional file 6}

GC-MS SIM spectra for $\mathrm{GA}_{5}$ in culture filtrate of wild type G. fujikuroi. Arrow indicates the peak of fungal $G A_{5}$ that coincides with that of internal standard $G A_{5}$.

Click here for file

[http://www.biomedcentral.com/content/supplementary/14712180-8-231-S6.pdf]

\section{Acknowledgements}

This research is a part of 'Eco-technopia 21 project' supported by Korea Ministry of Environment and a grant (Code\#2007040 I03402I) from Biogreen 21 program, rural development administration, Republic of Korea.

\section{References}

I. Tudzunski B: Fungal phytohormones in pathogenic and mutualistic associations. In The Mycota, Plant Relationship, Part A Volume V. Edited by: Esser K, Lemke PA. Springer-Verlag, Berlin; 1997:167-184.

2. Ogas J: Gibberellins. Current Biology 2000, 10:R48-R48.

3. Radely $M$ : Occurrences of substances similar to gibberellic acid in higher plants. Nature 1956, 178: 1070-107I.

4. Nishijima T, Koshioka M, Yamazaki H, Miura H, Mander LN: Endogenous gibberellins and bolting in cultivars of japanese radish. Acta Hort (ISHS) 1995, 394:199-206.

5. Martin GC: The Biochemistry and Physiology of Gibberellins. Volume 2. Edited by: Crozier A. Praeger, New York; 1983:395-444.

6. MacMillan J: Occurrence of gibberellins in vascular plants, fungi and bacteria. J Plant Growth Regul 2002, 20:387-442.

7. Kawaide $\mathrm{H}$ : Biochemical and molecular analysis of gibberellin biosynthesis in fungi. Biosci Biotechnol Biochem 2006, 70:583-590.

8. Tejesvi MV, Kini KR, Prakash HS, Ven Subbiah, Shetty HS: Genetic diversity and antifungal activity of species of Pestalotiopsis isolated as endophytes from medicinal plants. Fungal Diversity 2007, 24:37-54.

9. Carroll GC: The biology of endophytism in plants with particular reference to woody perennials. In Microbiology of the Phyllosphere Edited by: Fokkema NJ, Van Den Heuvel J. Cambridge University Press, Cambridge UK; 1 986:205-222. 
10. Sánchez Márquez, Bills GF, Zabalgogeazcoa I: The endophytic mycobiota of the grass Dactylis glomerata. Fungal Diversity 2007, 27:171-195.

II. Gonthier P, Gennaro M, Nicolotti G: Effects of water stress on the endophytic mycota of Quercus robur. Fungal Diversity 2006, 2 I :69-80.

12. Rodriguez R, Redman R: More than $\mathbf{4 0 0}$ million years of evolution and some plants still can't make it on their own: plant stress tolerance via fungal symbiosis. J Exp Bot 2008, 59: II09-III4.

13. Redman RS, Dunigan DD, Rodriguez RJ: Fungal symbiosis: from mutualism to parasitism, who controls the outcome, host or invader? New Phytologist 200 I, I 5 I:705-7 I6.

14. Redman RS, Sheehan KB, Stout RG, Rodriguez RJ, Henson JM: Thermotolerance conferred to plant host and fungal endophyte during mutualistic symbiosis. Science 2002, 298: I58I.

15. Arnold AE, Mejia LC, Kyllo D, Rojas E, Maynard Z, Robbins N, Herre EA: Fungal endophytes limit pathogen damage in a tropical tree. PNAS 2003, 100:15649-15654.

16. Waller F, Achatz B, Baltruschat H, Fodor J, Becker K, Fischer M, Heier T, Huckelhoven R, Neumann C, Von Wettstein D, Franken P, Kogel $\mathrm{KH}$ : The endophytic fungus Piriformis indica reprograms barley to salt-stress tolerance, disease resistance, and higher yield. PNAS 2005, I02: |3386-1339|.

17. Marquez LM, Redman RS, Rodriguez RJ, Roossinck MJ: A virus in a fungus in a plant-three way symbioses required for thermal tolerance. Science 2007, 3 1 5:513-515.

18. Schulz B, Boyle C: The endophytic continuum. Mycol Res 2005, I 09:66 |-686.

19. Dutta T, Sahoo R, Sengupta R, Ray SS, Bhattacharjee A, Ghosh S: Novel cellulases from an extremophilic filamentous fungi Penicillium citrinum: production and characterization. J Ind Microbiol Biotechnol 2007, 35:275-282.

20. Duncan SM, Farell RL, Thwaites JM, Held BW, Arenz BE, Jurgens JA, Blanchette RA: Endoglucanase-producing fungi isolated from Cape Evans historic expedition hut on Ross island, Antarctica. Env Microbio 2006, 8:1212-1219.

21. Kuramata M, Fujioka S, Shimada A, Kawano T, Kimura Y: Citrinolactones $A, B$ and $C$ and Sclerotonin $C$, plant growth promoters from Penicillium citrinum. Biosci Biotechnol Biochem 2007 7l:499-503.

22. Comerio R, Pinto VEF, Vaamonde G: Influence of water activity on Penicillium citrinum growth and kinetics of citrinin accumulation in wheat. Int J Food Microbiol 1998, 42:219-223.

23. Wakiyama M, Tanaka $\mathrm{H}$, Yoshihara K, Hayashi S, Ohta K: Purification and Properties of Family- 10 Endo-I,4- $\beta$-Xylanase from Penicillium citrinum and Structural Organization of Encoding Gene. J Biosci Bioeng 2008, I 05(4):367-374.

24. Girard $M$, Lavoie $C$, Theriault $M$ : The regeneration of a highly disturbed ecosystem: a mined peat land in southern Quebec. Ecosystems 2002, 5:274-288.

25. Kim KD: Invasive plants on disturbed Korean sand dunes. Estuarine Coastal and Shelf Science 2005, 62:353-364.

26. Kunkel G: Plants for Human Consumption. Koeltz Scientific Books 1984.

27. Hamayun M, Khan SA, Kim HY, Chaudhary MF, Hwang YH, Shin DH, Kim IK, Lee BH, Lee IJ: Gibberellin Production and Plant Growth Enhancement by Newly Isolated Strain of Scolecobasidium tshawytschae. I Microbiol Biotechnol 2008 in press.

28. Choi WY, Rim SO, Lee JH, Lee JM, Lee IJ, Cho KJ, Rhee IK, Kwon JB, $\mathrm{Kim}$ JG: Isolation of gibberellins producing fungi from the root of several Sesamum indicum plants. J Microbiol Biotechnol 2005, I 5:22-28.

29. Higgs RE, James AZ, Jeffrey DG, Matthew DH: Rapid method to estimate the presence of secondary metabolites in microbial extracts. Appl Environ Microbiol 2001, 67:371-376.

30. Cragg GM, Newman DJ, Snader KM: Natural products in drug discovery and development. I Nat Prod (Lloydia) 1997, 60:52-60.

31. Mitchell AM, Strobel GA, Hess WM, Vargas PN, Ezra D: Muscodor crispans, a novel endophyte from Ananas ananassoides. in the Bolivian Amazon. Fungal Diversity 2008, 31:37-43.

32. Kumar DSS, Lau CS, Wan JMF, Yang D, Hyde KD: Immunomodulatory compounds from Pestalotiopsis leucothës (HKUCC I 0 197), an endophytic fungus of Tripterygium wilfordii. Life Sciences 2005, 78:147-156.
33. Katona ZF, Sass P, Nolnar-Perl I: Simultaneous determination of sugars, sugar alcohols, acids and amino acids in apricots by gas chromatography-mass spectrometry. Anal Biochem 1999, 266:77-84.

34. Roessner U, Wagner C, Kopka J, Trethewey RN, Willmitzer L: Simultaneous analysis of metabolites in potato tuber by gas chromatography-mass spectrometry. Plant J 2000, 23:| 3 |- | 42.

35. Careri M, Bianchini F, Corradini C: Recent advances in the application of mass spectrometry in food-related analysis. J Chrom A 2002, 970:3-64.

36. Saevels S, Lammertyn J, Berna AZ, Veraverbeke EA, Di Natale C, Nicolai BM: An electronic nose and a mass spectrometrybased electronic nose for assessing apple quality during shelf life. Postharvest Biol Technol 2004, 3 I:9-19.

37. Cohen JD, Baldi BG, Slovin JP: '3C6 [benzene ring]-indole-3-acetic acid: a new internal standard for quantitative mass spectral analysis of indole-3-acetic acid in plants. Plant Physiol 1986, 80:14-19.

38. Cohen JD, Bausher MG, Bialek K, Buta JG, Gocal GFW , Janzen LM, Pharis RP, Reed AN, Slovin JP: Comparison of a Commercial ELISA Assay for Indole-3-Acetic Acid at Several Stages of Purification and Analysis by Gas Chromatography-Selected Ion Monitoring-Mass Spectrometry Using a '3C6-Labeled Internal Standard. Plant Physiol 1987, 84:982-986.

39. Schmelz EA, Engelberth J, Alborn HT, O'Donnell P, Sammons M, Toshima H, Tumlinson JH: Simultaneous Analysis of Phytohormones, Phytotoxins, and Volatile Organic Compounds in Plants. PNAS USA 2003, I00:10552-10557.

40. Franck C, Lammertyn J, Nicolaï B: Metabolic Profiling Using GCMS to Study Biochemical Changes during Long-Term Storage of Pears. the Proc 5th Int Postharvest Symp. Acta Hort 2005, 682: $1991-1998$

41. Hao C, Zhao X, Yang P: GC-MS and HPLC-MS analysis of bioactive pharmaceuticals and personal-care products in environmental matrices. Trends Anal Chem 2007, 26:569-580.

42. Sugita T, Nishikawa A: Fungal identification method based on DNA sequence analysis. Reassessment of the methods of the pharmaceutical society of Japan and the Japanese pharmacopoeia. J Health Sci 2003, 49:531-533.

43. Promputtha I, Jeewon R, Lumyong S, McKenzie EHC, Hyde KD: Ribosomal DNA fingerprinting in the identification of non sporulating endophytes from Magnolia liliifera (Magnoliaceae). Fungal Diversity 2005, 20:167-186.

44. Promputtha I, Jeewon R, Lumyong S, McKenzie EHC, Hyde KD: A phylogenetic evaluation of whether endophytes become saprophytes at host senenscence. Microbial Ecol 2007, 53:579-590.

45. Lee JS, Lee HK, Hur JS, Andreev M, Hong SG: Diversity of the Lichenized Fungi in King George Island, Antarctica, Revealed by Phylogenetic Analysis of Partial Large Subunit rDNA Sequences. J Microbiol Biotechnol 2008, I 8:1016-1023.

46. Kim KS, Lee YS: Rapid and accurate species-specific detection of Phytophthora infestans through analysis of ITS regions in its rDNA. J Microbiol Biotechnol 2000, 1 0:65 I-655.

47. Lee HG, Lee JY, Lee DH: Cloning and characterization of the ribosomal RNA gene from Gonyaulax polyerdra. J Microbiol Biotechnol 200 I, I I:5 I5-523.

48. Guo LD, Hyde KD, Liew ECY: Detection and Taxonomic Placement of Endophytic Fungi within Frond Tissues of Livistona chinensis Based on rDNA Sequences. Mol Phy Evo 2001, 20:1-13.

49. Yang C, Khuri S: PTC: An Interactive Tool for Phylogenetic Tree Construction. Proc Comp Sys Bioinfo 2003.

50. Yamada A, Ogura T, Degawa Y, Ohmasa M: Isolation of Tricholoma matsutake and $T$. bakamatsutake cultures from field-collected ectomycorrhizas. Mycoscience 200I, 42:43-50.

51. Modess O: Zur Kenntins der Mykorrhizabildner von Kiefer und Fichte. Symb Bot Upsal 194I, 5: I-146.

52. Hasan HAH: Gibberellin and auxin production plant root fungi and their biosynthesis under salinity-calcium interaction. Rostlinna vyroba 2002, 48(I): I01-106.

53. Bayman B, Lebron LL, Tremblay RL, Lodge DJ: Variation in endophytic fungi from roots and leaves of Lepanthes (Orchidaceae). New Phytol 1997, I35: I43-149.

54. Vazquez MM, Cesar S, Azcon R, Barea JM: Interaction between arbuscular mycorrhizal fungi and other microbial inoculants 
(Azospirillum, Pseudomonas, Trichoderma) and their effects on microbial population and enzyme activities in the rhizosphere of maize plants. Appl Soil Ecol 2000, I5:26I-272.

55. Mineo L: Plant tissue culture techniques. Tested studies in laboratory teachings Proc ABLE 1990, I I: I5 I-174.

56. Lee IJ, Foster K, Morgan PW: Photoperiod control of gibberellin levels and flowering in sorghum. Plant Physiol 1998, I16:1003-1011.

57. Tamura K, Dudley J, Nei M, Kumar S: Molecular Evolutionary Genetics Analysis (MEGA) software version 4.0. Mol Bio Evo 2007:1596-1599.

Publish with Bio Med Central and every scientist can read your work free of charge

"BioMed Central will be the most significant development for disseminating the results of biomedical research in our lifetime. "

Sir Paul Nurse, Cancer Research UK

Your research papers will be:

- available free of charge to the entire biomedical community

- peer reviewed and published immediately upon acceptance

- cited in PubMed and archived on PubMed Central

- yours - you keep the copyright

Submit your manuscript here:

http://www.biomedcentral.com/info/publishing_adv.asp
BioMedcentral 